\title{
Management of chilli thrips Scirtothrips dorsalis (Hood) (Thysanoptera: Thripidae) in chilli crop
}

\author{
Muhammad Yousaf ${ }^{1}$, Maqsood Shah ${ }^{1}$, Amjad Usman ${ }^{1}$, Jawad Sarwar ${ }^{\text {* }}$, \\ Junaid Iqbal ${ }^{1}$ and Ruidar Ali Shah ${ }^{2}$ \\ 1. Department of Entomology, The University of Agriculture, Peshawar-Pakistan \\ 2. Director ORIC, University of Swabi, Swabi-Pakistan \\ *Corresponding author's email: jsarwaraup@gmail.com \\ Citation \\ Muhammad Yousaf, Maqsood Shah, Amjad Usman, Jawad Sarwar, Junaid Iqbal and Ruidar Ali Shah. Management \\ of chilli thrips Scirtothrips dorsalis (Hood) (Thysanoptera:Thripidae) in chilli crop. Pure and Applied Biology. Vol. \\ 8, Issue 1, pp271-277. http://dx.doi.org/10.19045/bspab.2018.700185
}

Received: 26/09/2018 Revised: 05/11/2018

Accepted: 07/11/2018

Online First: 10/11/2018

\section{Abstract}

Evaluation of different management tactics against chilli thrips Scirtothrips dorsalis was carried at Agricultural Research Institute, Tarnab during 2016. Experiment was carried out in Randomized Complete Block Design (RCBD) with three replications. Six control measures i.e Solvigo 108SC, Confidor 200SC, Chrysoperla carnea, Parthenium hysterophorus 7\%, Combination-1 (P. hysterophorus $7 \%$ extract $+C$. carnea) and Combinaion-2 (P. hysterophorus $7 \%$ extract + Pest Oil@500 $\mathrm{ml} \mathrm{ha}^{-1}$ ) including control were applied twice at 30 days interval. Results revealed that all the tested control measures were found to be superior than control however in both the spray application Solvigo was found to be the most effective in reducing nymphal and adult thrips infestation with $(1.79,2.83)$ nymphal and $(0.49,0.85)$ adult population, followed by Confidor after first and Second spray respectively. C. carnea alone did not give significant control of thrips as compared to the plot where $C$. carnea were applied in combination with botanicals. Highest yield was obtained from the plots treated with Solvigo while the lowest yield was recorded from Control (untreated plots). It was concluded that Solvigo and Confidor were found to be better in managing chilli thrips infestation and can be incorporated in IPM programs against chilli thrips.

Keywords: Chilli thrips; Synthetic insecticide; Thrips management

\section{Introduction}

Chilli is an important commodity in the current time with its diverse qualities of providing vitamins, boasting the immune system, lower cholesterol level and is also helpful in getting rid of parasites of gut [1]. Chilli crop is attacked by many insect pests causing considerable loss in yield. Among them chilli thrips, Scirtothrips dorsalis is one of the major pest of chilli crop causing more than $25 \%$ damages under higher density attack [2]. Chilli thrips attacks foliage, with both adults and larvae preferentially feeding on young leaves, buds, and fruits. Feeding causes distortion and discoloration, and severe infestations can lead to defoliation and stunted growth [3]. In a severe pest attack the appropriate control measure is the application of insecticides with multiple applications [4]. C. carnea is a predator of wide range of soft 
bodied insect pest in Pakistan and belong to family Chrysopidae and order Neuroptera [5]. Larvae of $C$. carnea feed on thrips, jassids and whitefly and causes intermediate reduction in its population [6]. Chemical insecticide imidacloprid belong to neonicotinoid an insecticides class, effectively managed the chilli thrips population [7]. Apart from chemical control biocontrol agents such as minute pirate bugs, Oriusspp and the phytoseiid mites Neoseiulus cucumeris and Amblyseius swirskii and herbal extracts are also termed effective in controlling the pest population $[8,9]$. Hence the present study is an attempt to develop an IPM strategy to manage chilli thrips infestation.

\section{Materials and methods}

To study the effect of different treatments against chillithrips was conducted at Agriculture Research Institute (ARI) Tarnab, Peshawar during 2016. The experiment was conducted in randomized complete block design with three replications. Nursery of China Shimla variety was collected from local market, the field was prepared for transplantation of chilli crop according to standard agronomic practices. Transplantation of nursery was done in $2^{\text {nd }}$ week of March 2016 with total experimental area of $405 \mathrm{~m}^{2}$, divided into three blocks and each block was divided into seven plots. Size of each plot was $3 \times 5 \mathrm{~m}^{2}$ with buffer zone of 1 meter. Treatments included Solvigo 108SC (Abamectin 3.6\% and Thiamethoxim 7.2\%), Confidor 200SC (Imidacloprid), Herbal weed extract (P. hysterophorus) $7 \%$, Combination-1 [herbal extract $(P$. hysterophorus) $7 \%+C$. carnea (1000 eggs ha $\left.\left.^{-1}\right)\right]$ Combination-2 [herbal extract (P.hysterophorus) $7 \%$ + Pest oil $\left(500 \mathrm{ml} \mathrm{ha}^{-}\right.$

$\left.{ }^{1}\right)$ ] and control. All the control measures were applied twice with 3 weeks interval. Data were recorded on number of (nymph and adult/plant) thrips on randomly selected 15 plants in each plot after 24, 48, 72 hours and one week interval. Mean data on thrips nymph and adults were then subjected to computer software Statistix Ver 8.1 for analysis. Formula used during the experiment;

Avoidable losses $(\%)=\frac{\mathrm{A}-\mathrm{B}}{\mathrm{A}} \times 100$

$A=$ Total Yield of a Treated Yield

$\mathrm{B}=$ Yield of control plot

Results and discussion

Effect of different control measures on nymphal population of thrips in chilli crop during 2016

Table 1 shows the effect of different treatments on nymphal population of chilli thrips recorded after (24, 48 and 72) hours and 1 week. In first spray application Solvigo was found to be the most effective insecticide with the least mean population of (1.79) thrips plant ${ }^{-1}$ followed by Confidor (1.94), Combination-1 (4.43), Combination-2 (4.48), P. hysterophorous (5.22) and $C$. carnea (8.10) thrips plant ${ }^{-1}$. Similar trend has been observed during the second course of application of control measures in minimizing the pest population Solvigo (2.83) having the most impact followed by Confidor (3.17), Combination-1 (5.32), Combination-2 (6.56), P. hysterophorous (6.97) and C. carnea (9.18) thrips plant ${ }^{-1}$. Our results showed that chemical application reduced the pest population significantly which results in a similar pattern with that of [10]. They applied different chemicals to apprehend the chillithrips attack in the field. Imidaclropid being the second most successful chemical as compare to the other insecticides to control the population of thrips. [11] used Confidor and different other chemicals and botanical extract in order to minimize the harmful effects of chilli thrips. Confidor being the third most effective chemical in managing the population of thrips while botanical extracts i.e. neem appeared to be an effective control measure in this experiment as compared to control. 
Our study is also coherence with [12], they applied chemical similar to Salvigo in chemical structure and method of application and found that management of chillithrips through chemicals is quite effective, and $90 \%$ control was achieved in comparison to the untreated plot. It was also noted that nymph population of thrips before $1^{\text {st }}$ spray is quite low as compare to nymph population before $2^{\text {nd }}$ spray because the population reaches its peak in April-May, [13] also recorded same pattern in population dynamics of thrips.

Effect of different control measures on adult population of thrips in chilli crop during 2016

Table 2 shows the effect of different treatments on adult population of chilli thrips noted after (24, 48 and 72) hours and 1 week. Solvigo was found to be the most effective insecticide with the least thrips infestation of (0.49) thrips plant $^{-1}$ followed by Confidor (1.47), Combination-2 (4.10), Combination1 (4.63), P. hysterophorous (4.72) and $C$. carnea (7.52) thrips plant ${ }^{-1}$. Similar trend has been observed during the second course of application of control measures in minimizing the pest population Solvigo (0.85) having the most impact followed by confidor (1.94), Combination-2 (3.90), Combination-1 (4.61), P. hysterophorous (5.23) and C. carnea (7.87) thrips plant ${ }^{-1}$. Our research study showed that $C$. carnea was less effective to control chilli thrips. This could be due to $C$. carnea is least acive at high temperatures, which results in the lower outcome of its abilities to enhance the integration measures to control chilli thrips. Our results were also supported by [14] as they reported that $C$. carnea is effective between $28-32^{\circ} \mathrm{C}$ and with the rise in temperature had an adverse impact on the ability of $C$. carnea to predate. Our study also showed that $C$. carnea less much effective this is may be due to the reason that lower number of eggs (1000 eggs ha-1) installed in the field couldn't provide significant control of the pest. [15] Conducted field experiment comprising of $C$. carnea (1500 eggs ha-1) against thrips and reported that $C$. carnea proved to be effective in reducing pest population. [16] Also reported that with $C$. carnea is effective against thrips if used in a combination with other tactics could yield appreciating results. [17] Applied several plant extracts including $P$. hysterophorous against thrips and reported that it provided significant control of the pest. Pest oil applied during the experiment also performed well in combination with biopesticide and revealed that synergist can be helpful when used in combination. Similar observation were also made by [18] that plant extracts used in combination with pesticide can aid in reducing the population of various insects. Also population of adult is low as compare to nymph population of thrips because of the effective pesticide application, it is also recorded that nymph stage is more susceptible to pesticide application than adult stage even at the same dose. Our results can be compared with that of [13] who reported that treatment with pesticide can effectively reduce the population of thrips. [19] Also recorded that application of insecticide can readily reduce the population of thrips. 
Table1. Effect of different control measures on nymphal population of thrips in chilli crop during 2016

\begin{tabular}{|c|c|c|c|c|c|c|c|c|c|c|}
\hline \multirow{3}{*}{ Treatments } & \multicolumn{10}{|c|}{ Nymph population plant $^{-1}$} \\
\hline & \multicolumn{5}{|c|}{$1^{\text {st }}$ spray application } & \multicolumn{5}{|c|}{$2^{\text {nd }}$ spray application } \\
\hline & 24hours & 48hours & 72hours & 1 week & Means & 24hours & 48hours & 72hours & 1week & Mean \\
\hline Solvigo & 1.37 & 1.51 & 1.82 & 2.46 & $1.79 \mathrm{~d}$ & 2.53 & 2.60 & 2.93 & 3.29 & $2.83 \mathrm{e}$ \\
\hline Confidor & 1.49 & 1.62 & 2.06 & 2.58 & $1.94 \mathrm{~d}$ & 2.69 & 2.73 & 3.13 & 4.13 & $3.17 \mathrm{de}$ \\
\hline C. carnea & 7.71 & 8.02 & 7.60 & 9.06 & $8.10 \mathrm{~b}$ & 8.00 & 8.53 & 8.16 & 12.02 & $9.18 \mathrm{~b}$ \\
\hline P. hysterophorus & 4.15 & 4.15 & 5.57 & 7.02 & $5.22 \mathrm{c}$ & 5.13 & 5.53 & 6.33 & 10.91 & $6.97 \mathrm{bc}$ \\
\hline Combination-1 & 4.04 & 4.04 & 3.37 & 6.26 & $4.43 \mathrm{c}$ & 5.08 & 5.30 & 5.60 & 10.26 & $6.56 \mathrm{c}$ \\
\hline Combination-2 & 4.18 & 4.18 & 4.22 & 5.35 & $4.48 \mathrm{c}$ & 5.09 & 5.26 & 5.53 & 5.40 & $5.32 \mathrm{~cd}$ \\
\hline Control & 14.84 & 15.13 & 15.62 & 17.26 & $15.71 \mathrm{a}$ & 15.75 & 16.06 & 17.10 & 18.27 & $16.79 \mathrm{a}$ \\
\hline Means & $5.40 \mathrm{~b}$ & $5.52 \mathrm{~b}$ & $5.75 \mathrm{~b}$ & $7.14 \mathrm{a}$ & & $6.32 \mathrm{~b}$ & $6.57 \mathrm{~b}$ & $6.97 \mathrm{~b}$ & $9.18 \mathrm{a}$ & \\
\hline LSD (Treatments) & \multicolumn{5}{|c|}{1.48} & \multicolumn{5}{|c|}{2.40} \\
\hline
\end{tabular}

Means with similar alphabets within rows and columns are non-significantly different at 0.05 level of probability

*Combination-1 [herbal extract (P. hysterophorus) $7 \%+$ C. carnea $\left(1000\right.$ eggs ha $\left.^{-1}\right)$ ]

*Combination-2 [herbal extract (P. hysterophorus) $7 \%+$ Pest oil $\left.\left(500 \mathrm{ml} \mathrm{ha}^{-1}\right)\right]$

Table 2. Effect of different control measures on adult population of thrips in chilli crop during 2016

\begin{tabular}{|c|c|c|c|c|c|c|c|c|c|c|}
\hline \multirow{3}{*}{ Treatments } & \multicolumn{10}{|c|}{ Adult population plant ${ }^{-1}$} \\
\hline & \multicolumn{5}{|c|}{$\mathbf{1}^{\text {st }}$ spray application } & \multicolumn{5}{|c|}{$2^{\text {nd }}$ spray application } \\
\hline & 24hours & 48hours & 72hours & 1week & Means & 24hours & 48hours & 72hours & 1week & Mean \\
\hline Solvigo & 0.15 & 0.24 & 0.42 & 1.15 & $0.49 \mathrm{~d}$ & 0.15 & 1.16 & 1.02 & 1.07 & $0.85 \mathrm{~d}$ \\
\hline Confidor & 0.26 & 1.31 & 2.30 & 2.01 & $1.47 \mathrm{~d}$ & 1.54 & 1.25 & 2.08 & 2.90 & $1.94 \mathrm{~d}$ \\
\hline C. carnea & 5.80 & 8.44 & 8.42 & 7.43 & $7.52 \mathrm{~b}$ & 5.96 & 8.26 & 7.82 & 9.44 & $7.87 \mathrm{~b}$ \\
\hline P. hysterophorus & 3.61 & 4.13 & 5.19 & 5.94 & $4.72 \mathrm{c}$ & 3.74 & 5.24 & 5.24 & 6.69 & $5.23 \mathrm{c}$ \\
\hline Combination-1 & 3.11 & 5.51 & 5.36 & 4.54 & $4.63 c$ & 3.03 & 5.11 & 3.73 & 6.56 & $4.61 \mathrm{c}$ \\
\hline Combination-2 & 3.17 & 4.31 & 4.69 & 4.23 & $4.10 \mathrm{c}$ & 3.00 & 4.69 & 3.78 & 4.13 & $3.90 \mathrm{c}$ \\
\hline Control & 9.40 & 12.09 & 11.65 & 14.81 & $11.99 \mathrm{a}$ & 10.56 & 12.00 & 11.33 & 12.95 & $11.71 \mathrm{a}$ \\
\hline Means & $3.64 b$ & $5.14 a$ & $5.43 a$ & $5.73 a$ & & $4.00 \mathrm{c}$ & $5.39 \mathrm{ab}$ & $5.00 \mathrm{bc}$ & $6.25 \mathrm{a}$ & \\
\hline LSD (Treatments) & \multicolumn{5}{|c|}{1.56} & \multicolumn{5}{|c|}{1.47} \\
\hline
\end{tabular}

Means with similar alphabets within rows and columns are non-significantly different at 0.05 level of probability

*Combination-1 [herbal extract (P. hysterophorus) $7 \%+C$. carnea $\left(1000\right.$ eggs ha $\left.^{-1}\right)$ ]

*Combination-2 [herbal extract (P.hysterophorus) $7 \%+$ Pest oil $\left(500 \mathrm{ml} \mathrm{ha}^{-1}\right)$ ] 
Effect of different treatments application on yield and \% avoidable losses

Table 3 revealed that application of different treatments had a prominent impact on population of thrips which resulted significant differences in yield. Highest yield was recorded from Solvigo (13244 $\mathrm{kg} \mathrm{ha}^{-1}$ ) followed by Confidor (11956 kg ha-1), Combination-2 (10311 kg ha $\left.{ }^{-1}\right)$, Combination-1 (9778 kg ha-1), C. carnea (7667 kg ha' $\left.{ }^{-1}\right) P$. hysterophorous $(8667 \mathrm{~kg}$ $\mathrm{ha}^{-1}$ ) and control (6689 $\mathrm{kg} \mathrm{ha}^{-1}$ ). In yield highest percent avoidable losses were recorded in plot treated with insecticides Solvigo (49.49\%) and Confidor (44.05\%) followed by combination-2 (35.12\%), combination-1 (31.59\%), $P$. hysterophorous $(22.82 \%) \quad$ while lowest percent avoidable loss was in $C$. carnea $(12.75 \%)$ compared with control plot. Results showed that insecticide used during the course of experiment suppressed the pest population significantly and enhanced crop yield while plots aided with $C$. carnea being the least effective in increasing the yield. [20] Reported significant higher yield from plot which were treated with synthetic insecticide and herbal extracts. [21] Used herbal and insecticide in combination and also reported high yield in combination treatments. [22] Applied different herbal extracts and chemical insecticides on onion crop and reported maximum yield in plots where chemical insecticides and herbal extracts are applied.

Table 3. Effect of different treatments application on yield and avoidable losses

\begin{tabular}{|c|c|c|}
\hline Treatments & Yield $\left(\mathbf{K g ~ h a}^{-\mathbf{1}}\right)$ & Avoidable loss (\%) \\
\hline Solvigo & $13244 \mathrm{a}$ & 49.49 \\
\hline Confidor & $11956 \mathrm{~b}$ & 44.05 \\
\hline C. carnea & $7667 \mathrm{e}$ & 22.75 \\
\hline P. hysterophorus & $8667 \mathrm{~d}$ & 31.59 \\
\hline Combination-1 & $9778 \mathrm{c}$ & 35.12 \\
\hline Combination-2 & $10311 \mathrm{c}$ & \\
\hline Control & $6689 \mathrm{f}$ & \\
\hline LSD(0.05) & & 0.58 \\
\hline
\end{tabular}

Means with similar alphabets within rows and columns are non-significantly different at 0.05 level of probability

*Combination-1 [herbal extract $(P$. hysterophorus $) 7 \%+C$. carnea $\left(1000\right.$ eggs ha $\left.\left.^{-1}\right)\right]$

*Combination-2 [herbal extract (P.hysterophorus) $7 \%+$ Pest oil $\left.\left(500 \mathrm{ml} \mathrm{ha}^{-1}\right)\right]$

\section{Conclusion}

It is concluded that all treatments showed tendency to reduce population of chilli thrips when compared with control. Maximum yield were observed in solvigo followed by confidor, while the least effective treatment was $P$. hysterophorus. Bio agent (C. carnea) also controls the population effectively but was less efficient than the insecticides. On the basis of present study it is recommended to apply Solvigo in combination with Confidor for effective control of chilli thrips.

\section{Author's contributions}

Conceived and designed the experiments: $\mathrm{M}$ Shah \& M Yousuf, Performed the experiments: A Usman, Analyzed the data: J Iqbal \& RA Shah, Wrote the paper: J Sarwar. References

1. Anonymous (2012). Manual on Good Agricultural Marketing Practices for Chilli. Govt of India, Ministry of Agric (Dept Agric\& Cooperation) Directorate of Marketing \& Inspection.

2. Kandasamy C, Mohansundaram P \& Karuppuchamy (1990). Evaluation of insecticides for the control of Scirtothrips dorsalis Hood, on chillies (Capsicum annum L.). Madras Agric J 77 (3-4): 169-172. 
3. Venette RC \& Davis EE (2004). Chilli thrips/yellow thrips, Scirtothrips dorsalis Hood (Thysanoptera: Thripidae). Mini Pest Risk Assessment. Univ. Minnesota. pp 31.

4. Bethke J, Chamberlin J, Dobbs J, Faver M, Heinz K, Lindquist R, Ludwig S, Mckenzie CL, Murphy G, Oetting R, Osborne L, Palmer C, Parrella M, Rechcigl N \& Yates R (2010). Thrips management program for plants for planting. Mid Florida Research \& Education Center, Univ. Florida. pp 1-9.

5. Nadeem S, Hamed M, Nadeem MK, Hasnain M, Atta BM, Saeed NA \& Ashfaq M (2012). Comparative study of developmental and reproductive characteristics of Chrysoperla carnea (Stephens) (Neuroptera: Chrysopidae) at different rearing temperatures. J Anim Plant Sci 22(2): 399-402.

6. Abbas Q, Arif MJ, Gogi MD, Abbas SK \&Karar H(2012). Performance of Imidacloprid, thiomethoxam, acetamaprid and a bio control agent (Chrysoperla carnea) against Whitefly, Jassid and Thrips on different cotton cultivars. W J Zool 7(2): 141-146.

7. Kumar V, Kakkar G, Cindy ML, Seal D \& Osborne L (2013). An Overview of ChilliThrips, Scirtothrips dorsalis (Thysanoptera: Thripidae) Biology, Distribution and Management. Chapter: 3, Publisher: Intech, Editors: Sonia Soloneski and Marcelo Larramendy, pp 53-77.

8. Dogramaci M, Arthurs SP, Chen J, McKenzie CL, Irrizary F \& Osborne LS (2011). Management of Chilli thrips Scirtothrips dorsalis (Thysanoptera: Thripidae) on peppers by Amblyseius swirskii (Acari: Phytoseiidae) and Oriusinsidiosus (Hemiptera: Anthocoridae). Biol Cont 59(3): 340347.
9. Arthurs S, Mckenzie CL, Chen J, Dogramaci M, Brennan M, Houben K \& Osborne L(2009). Evaluation of Neoseiulus cucumeris and Amblyseius swirskii (Acari: Phytoseiidae) as biological control agents of chillithrips, Scirtothrips dorsalis (Thysanoptera: Thripidae) on pepper. BiolCont 49(1): 91-96.

10. Seal D, Ciomperlik RM, Richards ML \& Klassen W (2006). Comparative effectiveness of chemical insecticides against the chilli thrips, Scirtothrips dorsalis Hood (Thysanoptera: Thripidae), on pepper and their compatibility with natural enemies. Crop Prot 25: 949-955.

11. Pandey S, Singh BK \& Gupta RP (2014). Effect of neem based botanicals, chemicals and bio-insecticides for the management of thrips in onion. Indian $J$ Agric Res 47(6): 545-548.

12. Vanisree K, Upendhar S, Rjasekhar P \& Rao GR (2017). Effect of newer insecticides against chilli thrips Scirtothrips dorsalis (Hood). J Entomol Zool 5(2): 277-284.

13. Ullah F, Mulk MU, Farid A, Saeed MQ $\&$ Sattar S (2010). Population Dynamics and Chemical Control of Onion Thrips (Thrips tabaci, Lindemann). Pakistan J Zool 42(4): 401-406.

14. Saljoqi AUR, Asad N, Khan J, Haq EU, Rehman S, Huma Z, Saeed HG, Nadeem M, Salim M, Ahmad B \&Zada H (2015). The impact of temperature on biological and life table parameters of Chrysoperla carnea Stephens (Neuroptera: Chrysopidae) fed on cabbage aphid, Brevicoryne brassicae (Linneaus). J Entomol Zool Studies 3(2): 238-242.

15. Mari JM (2012). Use of Chrysoperla carnea and Trichogramma chilonis (Ishii) on the population of insect pests in chilli ecosystem. Proc. 2nd Annual 
International Conference Syiah Kuala University.

16. Hanumantharaya L, Basavana GK \& Ramegowda GK (2008). Use of Green Lacewing, Chrysoperla carnea (Stephens) and Neem Seed Kernel Extract for Management of Insect Pests on Cotton. Karnataka J Agric Sci 21 (1): 41-44.

17. Shiberu T \& Negeri M (2014). Evaluation of insecticides and botanicals against Onion thrips, Thrips tabaci (L) (Thysanoptera: Thripidea). Entomol Appl Sci Letters 1(2): 26-30.

18. Odewole AF, Alao FB, Agboola AA \& Adedapo BF (2014). Comparative efficacy of plant extracts with synthetic against insect pests of okra (Abelmoschuse sculentus L. Monech). Inter Letters Nat Sci 14: 52-58.

19. Din N, Ashraf M \& Hussain S (2016). Effect of different non-chemical and chemical measures against onion thrips. J Entomol Zool Studies 4(5): 10-12.

20. Fitiwy I, Gebretsadkan A \& Ayimut KM (2015). Evaluation of botanicals for onion thrips, Thrip stabaci Lindeman, (Thysanoptera: Thripidae) control at Gum Selassa, South Tigray, Ethiopia. Momona Ethiopian J Sci 7(1): 32-45.

21. Shah RA (2015). Distribution and management of Thrips tabaci (Lindeman) (Thysanoptera: Thripidea) on onion (Allium cepa) in selected districts of Khyber Pakhtunkhwa province Pakistan. PhD Thesis. Dept. of Entomol, Univ. Agric. Peshawar, pp 122.

22. Hussain A (2016). Evaluation of different dosed of botanicals extracts against the onion Thrips (Thrips tabaci) on onion crop at Peshawar. M.Sc (Hons) Thesis. Dept. of Plant Protec, Univ. Agri. Peshawar, pp 46. 